\title{
Choroidal atrophy in a patient with paraneoplastic retinopathy and anti-TRPMI antibody
}

This article was published in the following Dove Press journal:

Clinical Ophthalmology

5 February 2014

Number of times this article has been viewed

\author{
Shinji Ueno' \\ Yasuki Ito' \\ Ruka Maruko' \\ Mineo Kondo ${ }^{2}$ \\ Hiroko Terasaki' \\ 'Department of Ophthalmology, \\ Nagoya University Graduate School \\ of Medicine, Nagoya, ${ }^{2}$ Department \\ of Ophthalmology, Mie University \\ Graduate School of Medicine, Tsu, \\ Japan
}

Correspondence: Shinji Ueno Department of Ophthalmology, Nagoya University Graduate School of Medicine, 65 Tsuruma-cho, Showa-ku, Nagoya 466-8550, Japan Tel +8I5 27442277

Fax +8I5 27442278

Email ueno@med.nagoya-u.ac.jp

\begin{abstract}
The purpose of this paper is to report choroidal atrophy in a patient with cancer-associated retinopathy who had autoantibodies against the transient receptor potential cation channel, subfamily M, member 1 (TRPM1). A 69-year-old man visited our clinic in July 2010 with complaints of blurred vision and night blindness in both eyes. The full-field electroretinograms were negative type, indicating ON bipolar cell dysfunction. General physical examination revealed small cell carcinoma of the lung, and Western blot of the patient's serum showed autoantibodies against TRPM1. We diagnosed this patient with cancer-associated retinopathy and retinal ON bipolar dysfunction due to anti-TRPM1 autoantibody. We followed him for more than 2 years from the initial visit and his symptoms have not changed. However, consistent with the choroidal hypopigmentation of the fundus, spectral domain optical coherence tomography showed a decrease in choroidal thickness of about one third over a 2-year follow-up period. We suggest that this case of gradually progressive choroidal atrophy was caused by the autoantibody against TRPM1 directly, because TRPM1 is expressed not only on ON bipolar cells but also on melanocytes. These findings indicate that we should be aware of choroidal thickness in patients with paraneoplastic retinopathy who have retinal ON bipolar dysfunction with the anti-TRPM1 antibody.
\end{abstract}

Keywords: choroidal thickness, melanocyte, TRPM1, cancer-associated retinopathy, paraneoplastic retinopathy

\section{Introduction}

The paraneoplastic retinopathies (PR) are a group of eye diseases characterized by progressive dysfunction of the retina and are caused by an antibody against the protein of a systemic neoplasm. Some PR patients, including those with melanoma-associated retinopathy, have ON bipolar cell dysfunction. ${ }^{1-4}$ The scotopic full-field electroretinograms (ERGs) elicited by bright flash stimuli have a negative-type shape with normal a-wave amplitudes and reduced b-wave amplitudes. The negative-type ERGs resemble those recorded from patients with complete-type congenital stationary night blindness. ${ }^{5}$ ERG findings suggest that the retinal ON bipolar cells are affected in patients with melanoma-associated retinopathy. ${ }^{2,6}$

Evidence has been obtained showing that a protein associated with the transient receptor potential cation channel, subfamily $M$, member 1 (TRPM1) is the antigen for the autoantibody against ON bipolar cells in PR patients. ${ }^{7,8}$ TRPM1, a member of the TRPM subfamily of TRP proteins, is a cation channel expressed on retinal ON bipolar cells. TRPM1 was originally discovered as a melanocyte-specific gene that was silenced in aggressive melanoma cells, but the functional characteristics of this 
protein in melanocytes have not been fully determined. ${ }^{9}$ It was later found to be an ion-conducting plasma membrane channel on retinal $\mathrm{ON}$ bipolar cells. ${ }^{10-12}$

We describe a new finding in a PR patient with antiTRPM1 antibody who had not only ON bipolar dysfunction but also severe choroidal atrophy. The Nagoya University Hospital ethics review board approved this report (approval ID 1131).

\section{Case report}

A 69-year-old man visited our clinic in July 2010 with complaints of blurred vision and night blindness in both eyes. Our initial examination found that his best-corrected visual acuity in decimal units was 1.0 in the right eye and 0.6 in the left eye. His refractive error was $+3.0 \mathrm{D}$ and $+3.5 \mathrm{D}$ for the right eye and left eye, respectively. Full-field rod ERGs were absent and cone-rod mixed responses were the negative type, indicating ON bipolar cell dysfunction (Figure 1). From the symptoms and ophthalmic examination, he was suspected of having PR.

A general physical examination revealed small cell carcinoma of the lung and Western blot of the patient's serum showed autoantibodies against TRPM1. We diagnosed this patient with melanoma-associated retinopathy and retinal ON bipolar dysfunction due to TRPM1 autoantibody and have reported his findings in more detail elsewhere. ${ }^{8}$ After diagnosis, chemotherapy was started using cisplatin and etoposide combined with radiation for the lung cancer in August 2010. The patient achieved a complete remission, but underwent cranial irradiation in March 2011 to prevent brain metastasis.

We have followed this patient ophthalmologically for more than 2 years since his initial visit and his symptoms have not changed. His best-corrected visual acuity decreased slightly to 0.8 in the right eye and 0.5 in the left eye due to progression of cataracts. His visual field has not constricted and his ERGs have not changed (see Figure 1). Rod responses were nonrecordable in 2010 and 2012. The amplitudes for a-wave of conerod mixed maximum response were $240 \mu \mathrm{V}$ and $220 \mu \mathrm{V}$ in 2010 and 2012, respectively, and those for b-wave were $150 \mu \mathrm{V}$ and $120 \mu \mathrm{V}$, respectively. The amplitudes of cone response were about $25 \mu \mathrm{V}$ for the a-wave and $50 \mu \mathrm{V}$ for the b-wave at both times in 2010 and 2012. The amplitudes of the $30 \mathrm{~Hz}$ flicker ERGs were $14 \mu \mathrm{V}$ in 2010 and $11 \mu \mathrm{V}$ in 2012. The difference in the ERGs was most likely within the error of measurement and not due to differences in retinal function. However, fundus photographs taken in October 2012 showed diffuse choroidal hypopigmentation in both eyes (Figure 2). We also found that the choroidal vessels were more visible than those obtained at the initial examination (Figure 2).

Spectral domain optical coherence tomography (Heidelberg Engineering, Heidelberg, Germany) showed a slight reduction in retinal thickness during the 2 years of follow-up, but the morphological architecture of the retina appeared almost normal at both times (Figure 3). Consistent with the choroidal hypopigmentation of the fundus, spectral domain optical coherence tomography showed a marked decrease in choroidal thickness over the 2-year period (Figure 3, arrowhead). Subfoveal choroidal thickness in the right eye measured manually was $250 \mu \mathrm{m}$ in $2010,180 \mu \mathrm{m}$ in 2011 , and $110 \mu \mathrm{m}$ in 2012, and for the left eye was $380 \mu \mathrm{m}$ in $2010,230 \mu \mathrm{m}$ in 2011, and $100 \mu \mathrm{m}$ in 2012.

\section{Discussion}

We reported a patient with cancer-associated retinopathy whose signs and electronegative ERG did not change but
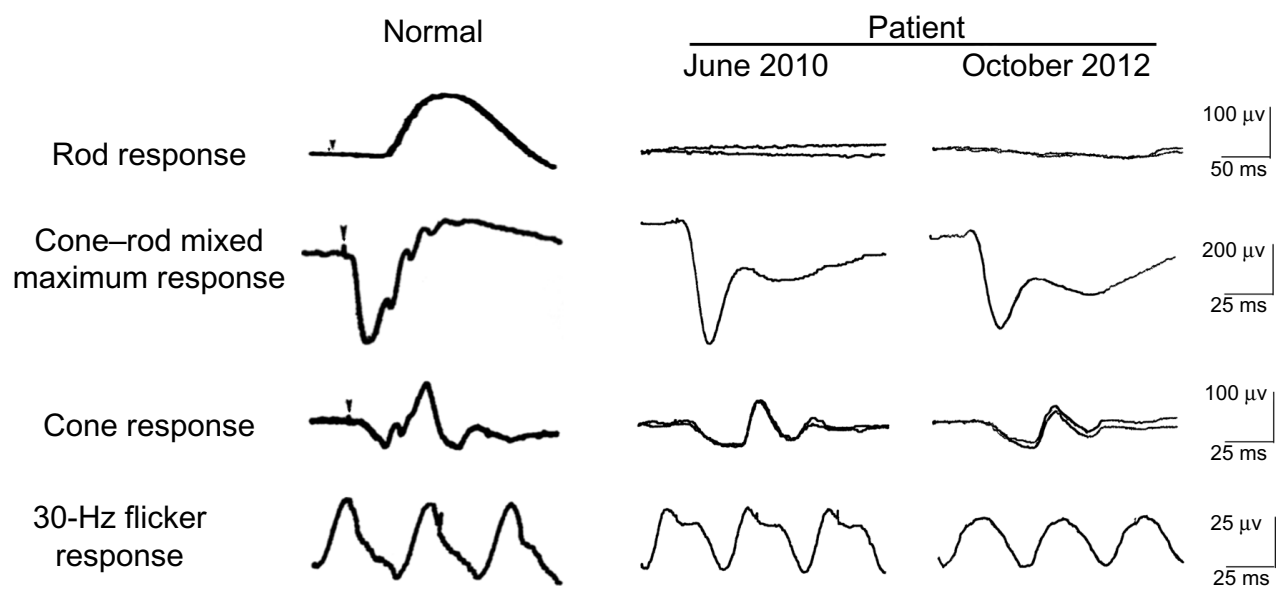

Figure I Scotopic electroretinograms elicited by a blue stimulus of $5.2 \times 10^{-3} \mathrm{~cd}-\mathrm{s} / \mathrm{m}^{2}$ after 30 minutes of dark adaptation. The cone-rod mixed maximum response was elicited by a white flash of $44.2 \mathrm{~cd}-\mathrm{s} / \mathrm{m}^{2}$. The cone response and a $30 \mathrm{~Hz}$ flicker response were elicited by white stimuli of $4 \mathrm{~cd}-\mathrm{s} / \mathrm{m}^{2}$ and $0.9 \mathrm{~cd}-\mathrm{s} / \mathrm{m}^{2}$, respectively, on a blue background of $30 \mathrm{~cd} / \mathrm{m}^{2}$. The electroretinograms were recorded on June 2010 and October 2012. 

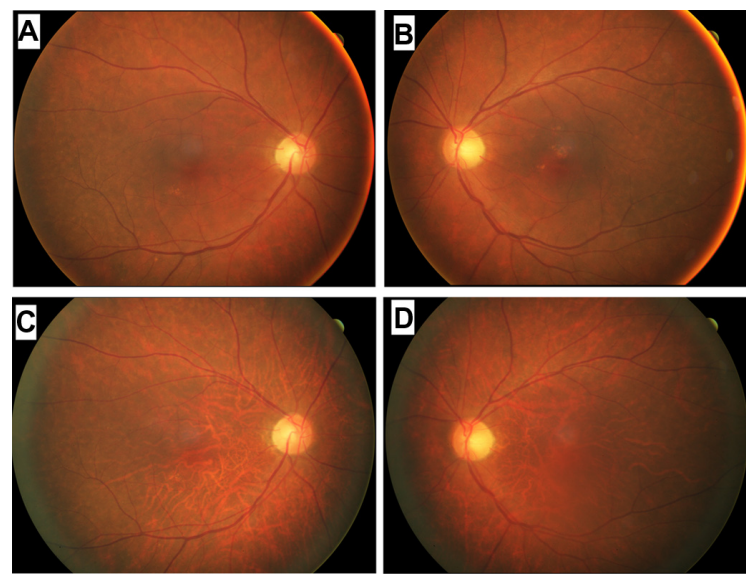

Figure 2 Fundus photographs of a patient diagnosed with carcinoma-associated retinopathy who developed choroidal atrophy during a 2-year follow-up period. Fundus photographs of the right (A) and left (B) eyes taken at the initial examination in June 2010. Fundus photographs of the right (C) and left (D) eyes taken in October 2012 .

thickness of the choroid decreased during a 2-year observation period. The natural course of cancer-associated retinopathy with retinal $\mathrm{ON}$ bipolar cell dysfunction and melanoma-associated retinopathy has not been fully determined, but one paper reported that symptoms and signs in most patients do not resolve. ${ }^{4}$ However, there have been some reports indicating recovery of various components of the ERG after treatment for the neoplasm. ${ }^{13-15}$ These differences may be due to differences in the antigen for the autoantibody.

There have been no reports describing choroidal thickness in PR patients with retinal ON bipolar cell dysfunction.
The choroid provides oxygen and nutrition to the outer retina. Recent advances in optical coherence tomography have enabled clinicians to obtain good quality images of the choroid. ${ }^{16} \mathrm{~A}$ thickening or thinning of the choroid has been reported in several retinochoroidal diseases, including central serous chorioretinopathy, ${ }^{17}$ Vogt-Koyanagi-Harada disease, ${ }^{18-20}$ age-related macular degeneration, ${ }^{21}$ and chorioretinal inflammatory disorders. ${ }^{22,23}$ However, to the best of our knowledge, this is the first report documenting thinning of the choroid in a patient with cancer-associated retinopathy.

Normal subfoveal choroidal thickness has been reported to be approximately $280 \mu \mathrm{m} .{ }^{16}$ At initial examination, the choroid was slightly thicker than this in our patient, but was still within the normal range. The choroidal thickness then decreased during the 2-year follow-up period. An unexpected finding was that the choroid became thinner by about one third of normal thickness in only 2 years. We suspect that this gradually progressive choroidal atrophy was caused directly by the autoantibody against TRPM1, because TRPM1 is expressed not only on ON bipolar cells but also on melanocytes ${ }^{9}$ and the choroid contains many melanocytes. The role of TRPM1 in melanocytes has not been fully determined; however, patients with complete-type congenital stationary night blindness and TRPM1 mutations do not show any detectable choroidal or skin pigment abnormalities, ${ }^{24}$ and TRPM1 knockout mice have a normal coat color phenotype. ${ }^{11}$ However, downregulation of TRPM1 in the retina and skin has been reported to be associated with

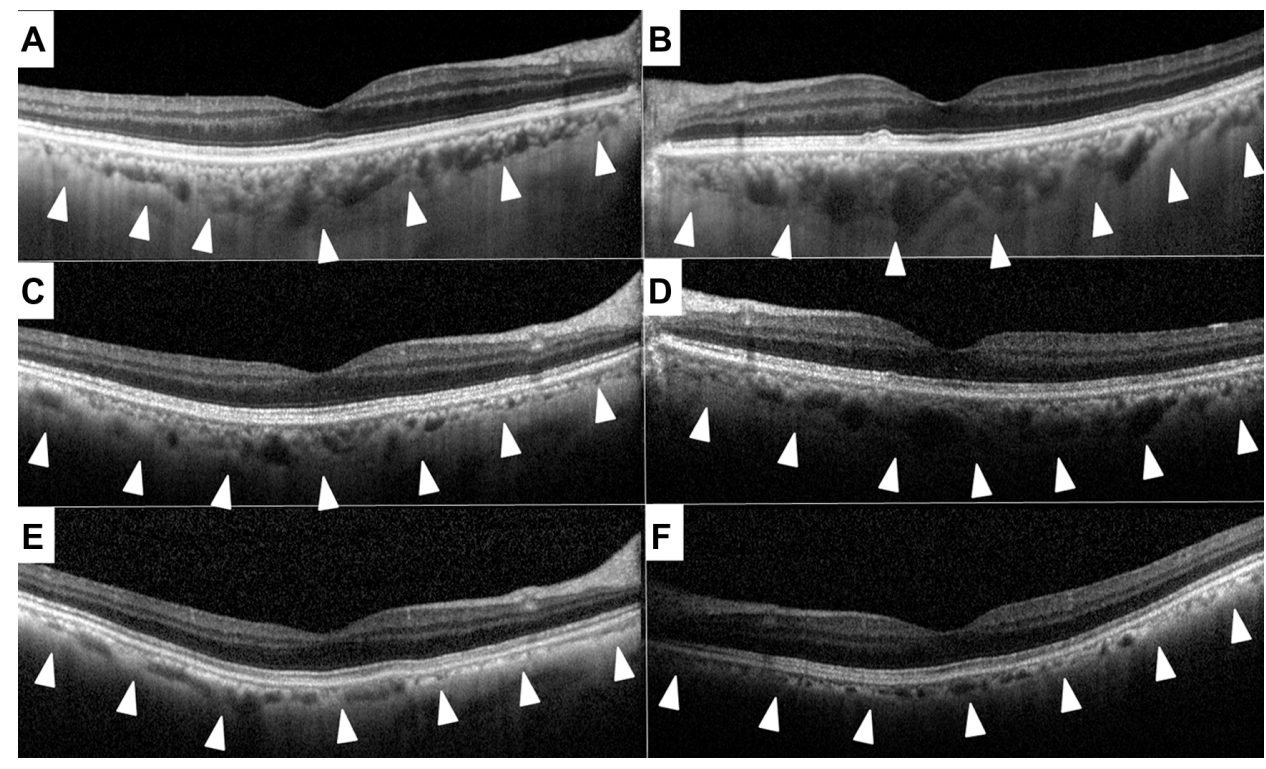

Figure 3 Spectral domain optical coherence tomographic images showing progressive choroidal thinning. These images were recorded in June 2010 (A, right; B, left), July 201 I (C, right; D, left), and October 2012 (E, right; F, left). Arrowhead shows the lower border of the choroid. 
the spotting pattern and congenital stationary night blindness in Appaloosa horses, suggesting a role for TRPM1 in melanogenesis. ${ }^{25}$ Recent reports show that TRPM1 is involved in the growth and differentiation of melanocytes by regulating ion homeostasis. ${ }^{26-28}$ In our patient, impairment of homeostasis in choroidal melanocytes due to anti-TRPM1 antibodies might have led to choroidal atrophy. However, to determine the exact relationship between the anti-TRPM1 antibody and choroidal melanocytes, in vitro experiments may be needed in the future.

One interesting finding was that the patient had no symptoms, and his best-corrected visual acuity and ERGs did not change significantly. This indicates that the minimum required amount of blood flow was preserved in spite of the choroidal atrophy. There is also a possibility that radiation or chemotherapy caused the choroidal thinning, but there have not been any other reports of choroidal atrophy due to treatment for cancer.

In conclusion, we report a patient with cancer-associated retinopathy and anti-TRPM1 autoantibodies who developed gradual choroidal atrophy over 2 years. The findings in our case indicate that we should be aware of choroidal thickness in PR patients with retinal ON bipolar cell dysfunction and anti-TRPM1 antibodies. Further examination of patients with PR is needed to evaluate the relationship between the anti-TRPM1 antibody and choroidal atrophy.

\section{Acknowledgment}

We thank Professor Duco I Hamasaki for discussions and editing the manuscript.

\section{Disclosure}

The authors report no conflicts of interest in this work.

\section{References}

1. Berson EL, Lessell S. Paraneoplastic night blindness with malignant melanoma. Am J Ophthalmol. 1988;106(3):307-311.

2. Alexander KR, Fishman GA, Peachey NS, Marchese AL, Tso MOM. ON response defect in paraneoplastic night blindness with cutaneous malignant-melanoma. Invest Ophthalmol Vis Sci. 1992;33(3): 477-483.

3. Milam AH, Saari JC, Jacobson SG, Lubinski WP, Feun LG, Alexander KR. Autoantibodies against retinal bipolar cells in cutaneous melanomaassociated retinopathy. Invest Ophthalmol Vis Sci. 1993;34(1): 91-100.

4. Keltner JL, Thirkill CE, Yip PT. Clinical and immunologic characteristics of melanoma-associated retinopathy syndrome: eleven new cases and a review of 51 previously published cases. J Neuroophthalmol. 2001;21(3):173-187.

5. Miyake Y, Yagasaki K, Horiguchi M, Kawase Y, Kanda T. Congenital stationary night blindness with negative electroretinogram - a new classification. Arch Ophthalmol. 1986;104(7):1013-1020.
6. Sieving PA, Murayama K, Naarendorp F. Push-pull model of the primate photopic electroretinogram - a role for hyperpolarizing neurons in shaping the b-wave. Vis Neurosci. 1994;11(3):519-532.

7. Dhingra A, Fina ME, Neinstein A, et al. Autoantibodies in melanomaassociated retinopathy target TRPM1 cation channels of retinal ON bipolar cells. J Neurosci. 2011;31(11):3962-3967.

8. Kondo M, Sanuki R, Ueno S, et al. Identification of autoantibodies against TRPM1 in patients with paraneoplastic retinopathy associated with ON bipolar cell dysfunction. PLoS One. 2011; 6(5):e19911.

9. Duncan LM, Deeds J, Hunter J, et al. Down-regulation of the novel gene melastatin correlates with potential for melanoma metastasis. Cancer Res. 1998;58(7):1515-1520.

10. Morgans CW, Zhang J, Jeffrey BG, et al. TRPM1 is required for the depolarizing light response in retinal ON-bipolar cells. Proc Natl Acad Sci U S A. 2009;106(45):19174-19178.

11. Koike C, Obara T, Uriu Y, et al. TRPM1 is a component of the retinal ON bipolar cell transduction channel in the mGluR6 cascade. Proc Natl Acad Sci U S A. 2010;107(1):332-337.

12. Koike C, Numata T, Ueda H, Mori Y, Furukawa T. TRPM1: a vertebrate TRP channel responsible for retinal ON bipolar function. Cell Calcium. 2010;48(2-3):95-101.

13. Anastasakis A, Dick AD, Damato EM, Spry PG, Majid MA. Cancer-associated retinopathy presenting as retinal vasculitis with a negative ERG suggestive of on-bipolar cell pathway dysfunction. Doc Ophthalmol. 2011;123(1):59-63.

14. Kim LS, Alexander KR, Fishman GA. Spontaneous improvement of rod system function in a patient with melanoma-associated retinopathy. Retin Cases Brief Rep. 2008;2(2):166-171.

15. Stead RE, Fox MA, Staples E, Lim CS. Delayed presentation of melanoma-associated retinopathy and subsequent resolution with cytoreduction surgery. Doc Ophthalmol. 2013;127(2):165-171.

16. Margolis R, Spaide RF. A pilot study of enhanced depth imaging optical coherence tomography of the choroid in normal eyes. Am J Ophthalmol. 2009;147(5):811-815.

17. Nicholson B, Noble J, Forooghian F, Meyerle C. Central serous chorioretinopathy: update on pathophysiology and treatment. Surv Ophthalmol. 2013;58(2):103-126.

18. Maruko I, Iida T, Sugano Y, et al. Subfoveal choroidal thickness after treatment of Vogt-Koyanagi-Harada disease. Retina. 2011;31(3): 510-517.

19. Nakai K, Gomi F, Ikuno Y, et al. Choroidal observations in Vogt-Koyanagi-Harada disease using high-penetration optical coherence tomography. Graefes Arch Clin Exp Ophthalmol. 2012;250(7): 1089-1095

20. Nakayama M, Keino H, Okada AA, et al. Enhanced depth imaging optical coherence tomography of the choroid in Vogt-Koyanagi-Harada disease. Retina. 2012;32(10):2061-2069.

21. Manjunath V, Goren J, Fujimoto JG, Duker JS. Analysis of choroidal thickness in age-related macular degeneration using spectral-domain optical coherence tomography. Am J Ophthalmol. 2011;152(4): 663-668.

22. Zhang X, Zuo C, Li M, Chen H, Huang S, Wen F. Spectral-domain optical coherence tomographic findings at each stage of punctate inner choroidopathy. Ophthalmology. 2013;120(12):2678-2683.

23. Regatieri CV, Branchini L, Fujimoto JG, Duker JS. Choroidal imaging using spectral-domain optical coherence tomography. Retina. 2012;32(5):865-876.

24. Li Z, Sergouniotis PI, Michaelides M, et al. Recessive mutations of the gene TRPM1 abrogate ON bipolar cell function and cause complete congenital stationary night blindness in humans. Am J Hum Genet. 2009;85(5):711-719.

25. Bellone RR, Brooks SA, Sandmeyer L, et al. Differential gene expression of TPLPM1, the potential cause of congenital stationary night blindness and coat spotting patterns (LP) in the appaloosa horse (Equus caballus). Genetics. 2008;179(4):1861-1870. 
26. Devi S, Kedlaya R, Maddodi N, et al. Calcium homeostasis in human melanocytes: role of transient receptor potential melastatin 1 (TRPM1) and its regulation by ultraviolet light. Am J Physiol Cell Physiol. 2009;297(3):C679-C687.

27. Oancea E, Vriens J, Brauchi S, Jun J, Splawski I, Clapham DE. TRPM1 forms ion channels associated with melanin content in melanocytes. Sci Signal. 2009;2(70):ra21.
28. Devi S, Markandeya Y, Maddodi N, et al. Metabotropic glutamate receptor 6 signaling enhances TRPM1 calcium channel function and increases melanin content in human melanocytes. Pigment Cell Melanoma Res. 2013;26(3):348-356.

\section{Publish your work in this journal}

Clinical Ophthalmology is an international, peer-reviewed journal covering all subspecialties within ophthalmology. Key topics include: Optometry; Visual science; Pharmacology and drug therapy in eye diseases; Basic Sciences; Primary and Secondary eye care; Patient Safety and Quality of Care Improvements. This journal is indexed on

Submit your manuscript here: http://www.dovepress.com/clinical-ophthalmology-journal

\section{Dovepress}

PubMed Central and CAS, and is the official journal of The Society of Clinical Ophthalmology (SCO). The manuscript management system is completely online and includes a very quick and fair peer-review system, which is all easy to use. Visit http://www.dovepress.com/ testimonials.php to read real quotes from published authors. 